\title{
LIVING CLASS IN URBAN INDIA
}





\section{LIVING CLASS IN URBAN INDIA}

SARA DICKEY

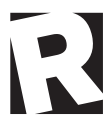

RUTGERS UNIVERSITY PRESS

New Brunswick, New Jersey, and London 
Library of Congress Cataloging-in-Publication Data

Names: Dickey, Sara, author.

Title: Living class in urban India / Sara Dickey.

Description: New Brunswick, New Jersey : Rutgers University Press, [2016] | Includes bibliographical references and index.

Identifiers: LCCN 201504I07I ISBN 978081358392I (hardcover : alk. paper) | ISBN 97808135839I4 (pbk. : alk. paper) ISBN 9780813583938 (ebook : epub) | ISBN 9780813583945 (ebook: Web PDF)

Subjects: LCSH: Social classes-India-Madurai-Longitudinal studies. | Social stratification-India-Madurai-Longitudinal studies. | Madurai (India)—Social conditions. | Madurai (India)—Economic conditions.

Classification: LCC HN690.M325 D53 2016 | DDC 306.30954/82-dc23

LC record available at http://lccn.loc.gov/201504107I

A British Cataloging-in-Publication record for this book is available from the British Library.

Copyright (C) 2016 by Sara Dickey

All rights reserved

No part of this book may be reproduced or utilized in any form or by any means, electronic or mechanical, or by any information storage and retrieval system, without written permission from the publisher. Please contact Rutgers University Press, I06 Somerset Street, New Brunswick, NJ 0890I. The only exception to this prohibition is "fair use" as defined by U.S. copyright law.

Visit our website: http:/ / rutgerspress.rutgers.edu

Manufactured in the United States of America 
To three guides,

Freddy Bailey, N. R. Chendur, V. Natarajan,

and to my father, Ward E. Dickey, a model as well 
